Article

\title{
Monitoring Physiological Changes in Haloarchaeal Cell during Virus Release
}

\author{
Julija Svirskaitè ${ }^{1}$, Hanna M. Oksanen ${ }^{1}$, Rimantas Daugelavičius ${ }^{2}$ and Dennis H. Bamford ${ }^{1, *}$ \\ 1 Department of Biosciences, Institute of Biotechnology, University of Helsinki, Viikinkaari 9, 00014 Helsinki, \\ Finland; julija.svirskaite@helsinki.fi (J.S.); hanna.oksanen@helsinki.fi (H.M.O.) \\ 2 Department of Biochemistry, Vytautas Magnus University, Vileikos g. 8, 44404 Kaunas, Lithuania; \\ r.daugelavicius@gmf.vdu.lt \\ * Correspondence: dennis.bamford@helsinki.fi; Tel.: +358-0-2941-59100
}

Academic Editor: Rob Lavigne

Received: 7 December 2015; Accepted: 15 February 2016; Published: 24 February 2016

\begin{abstract}
The slow rate of adsorption and non-synchronous release of some archaeal viruses have hindered more thorough analyses of the mechanisms of archaeal virus release. To address this deficit, we utilized four viruses that infect Haloarcula hispanica that represent the four virion morphotypes currently known for halophilic euryarchaeal viruses: (1) icosahedral internal membrane-containing SH1; (2) icosahedral tailed HHTV-1; (3) spindle-shaped His1; and (4) pleomorphic His2. To discern the events occurring as the progeny viruses exit, we monitored culture turbidity, as well as viable cell and progeny virus counts of infected and uninfected cultures. In addition to these traditional metrics, we measured three parameters associated with membrane integrity: the binding of the lipophilic anion phenyldicarbaundecaborane, oxygen consumption, and both intra- and extra-cellular ATP levels.
\end{abstract}

Keywords: Haloarcula hispanica; icosahedral membrane-containing virus SH1; icosahedral tailed virus HHTV-1; spindle-shaped virus His1; pleomorphic virus His2; potentiometry; virus life cycle; Pleolipoviridae; Sphaerolipoviridae

\section{Introduction}

Archaea are widespread in diverse ecosystems and dominate environments with elevated temperature, alkalinity, acidity, or salinity [1]. As for other unicellular organisms that thrive in harsh conditions, their cell envelope provides a protective barrier and also has a critical role in maintaining selective membrane permeability. However, archaeal membrane composition differs fundamentally from that of bacteria and eukaryotes. In archaea, isoprenoid hydrocarbon side chains are linked via an ether bond to the phosphate backbone [2], whereas, in bacteria and eukaryotes, fatty acids are linked by an ester bond. In general, archaea have only a single membrane that is typically surrounded by a paracrystalline protein layer, the S-layer. This outer protein layer gives the archaeal envelope its rigid surface and bestows on the cell a particular shape and surface qualities [3]. This, combined with the cytoplasmic membrane, forms a challenging barrier for archaeal viruses during both infection and progeny egress.

Since discovery of archaeal viruses in 1974 by Torsvik and Dundas [4], more than 130 archaeal viruses have been described, the majority of which ( 90) infect halophilic euryarchaea $[5,6]$. The most diverse and unique archaeal virus morphologies have been found among viruses infecting thermophilic crenarchaea [7], whereas only four morphotypes have been identified among the euryarchaeal viruses: icosahedral tailed, spindle-shaped, pleomorphic, and icosahedral with an internal membrane [5]. 
The mechanisms employed by archaeal viruses to release their progeny from the host cell have been rather elusive [8]. Two crenarchaeal viruses, Sulfolobus turreted icosahedral virus (STIV) and Sulfolobus islandicus rod-shaped virus 2 (SIRV2), are unique so far in utilizing an exit mechanism that involves the formation of pyramid structures in the cell membrane that open to release the progeny virions $[9,10]$. Among the euryarchaeal viruses, the only known gene product that could assist in virus release is a lytic enzyme, pseudomurein endoisopeptidase, identified in methanogenic euryarchaeal viruses $\psi \mathrm{M} 1$ and $\psi \mathrm{M} 2$ and prophage $\psi \mathrm{M} 100$ [11,12]. However, the function of the protein product has not been demonstrated, and no gene product active against archaeal S-layer has been identified yet. In contrast, several exit mechanisms have been described for DNA bacteriophages (phages). Numerous double-stranded (ds) DNA phages use a holin-endolysin system [13,14], whereas those with a small, single-stranded (ss) DNA genomes utilize a single-gene lysis mechanism [15] and filamentous phages are continuously extruded from their hosts [16]. Thus far, no archaeal virus genes display any sequence similarity to phage genes encoding exit-related functions. However, although no putative holins have been identified in the genomes of archaeal viruses, some have been found in archaeal genomes [13]. Probably, the fundamental difference in the cell envelopes of bacteria and archaea is one of the main factors driving the evolution of the divergent egress strategies of archaeal viruses and phages [17].

The diverse halophilic euryarchaeal viruses provide an opportunity to investigate these questions. Currently, only four haloarchaeal viruses have been shown to be temperate $(\varphi \mathrm{Ch} 1, \varphi \mathrm{H}, \mathrm{SNJ} 1$, and SNJ2), each either residing as a plasmid or integrating into the host cell chromosome [18-22]. The known haloarchaeal virus release mechanisms can be divided into two major categories: (i) those where the cell membrane is disrupted by host cell lysis; and (ii) those where the membrane remains intact (e.g., release by budding). Numerous halophilic archaeal viruses release their progeny continuously, apparently without causing host cell lysis [23,24]. A useful system for further investigation is provided by the halophilic euryarchaeon Haloarcula hispanica [25] that is infected by viruses representing the four known halophilic archaeal virus morphotypes [26-29] and also carries proviruses in its chromosome [19]. Four viruses were selected for this study, one from each morphotype: the icosahedral, internal membrane-containing virus $\mathrm{SH} 1$, spindle-shaped virus His1, pleomorphic virus His2, and icosahedral Haloarcula hispanica tailed virus 1 (HHTV-1) (Table 1). The genomes of all four are linear dsDNA and range in size between 15 and $50 \mathrm{kbp}$. When cultured in Har. hispanica cells, all four viruses reach high titers in the culture medium (Table 1). Receptors have not yet been identified for any euryarchaeal viruses, including these four.

Among the icosahedral viruses with an internal membrane, to date five (SH1, HHIV-2, PH1, SNJ1, and HCIV-1) are known to infect halophilic euryarchaeal hosts, either Haloarcula or Natrinema strains [18,30-33]. Only SNJ1 is known to be temperate, switching between lytic and lysogenic replication modes in a salt-concentration dependent manner [18,34]. SH1, the best-studied one and the one included in this study, recognizes host cells via horn-like spike complexes located at the five-fold vertices [31,35,36]. Host cell binding is most effective in high salinity [29]. Structurally SH1 is very similar to HHIV-2 that also infects Har. hispanica, but differs in that the host recognition spikes of HHIV-2 are pentameric, propeller-like complexes [35,37]. The lipids of SH1 are selectively acquired from the host plasma membrane during assembly. Progeny viruses are released from the host cell 5-6 h post infection (p.i.), with an average burst size of about 200 [27,31]. Thin-section transmission electron microscopy (TEM) analysis of SH1 infected Har. hispanica cells suggests a release mechanism based on cell membrane disruption [31]. In addition to Har. hispanica, SH1 also replicates in a Halorubrum isolate that resembles Halorubrum sodomense [31]. 
Table 1. Haloarcula hispanica SH1, HHTV-1, His1, and His2 viruses used in the study: virion and virus life cycle properties.

\begin{tabular}{|c|c|c|c|c|c|c|c|c|c|}
\hline Virus & $\begin{array}{c}\text { Virion } \\
\text { Morphotype }\end{array}$ & Lipids $^{1}$ & $\begin{array}{l}\text { Genome }^{3} \\
\text { (GenBank } \\
\text { Acc. No.) } \\
\end{array}$ & Virus Family ${ }^{4}$ & $\begin{array}{c}\text { Adsorption Rate } \\
\text { Constant } \\
(\mathrm{mL} / \mathrm{min})\end{array}$ & $\begin{array}{l}\text { Virus Release } \\
\text { Starts (h p.i.) }\end{array}$ & Virus Exit & $\begin{array}{l}\text { Progeny Viruses } \\
\text { at } 25 \mathrm{~h} \text { p.i. } \\
(\mathrm{pfu} / \mathrm{mL})\end{array}$ & References \\
\hline SH1 & Icosahedral & $\begin{array}{l}\text { Internal } \\
\text { membrane }\end{array}$ & $\begin{array}{c}30,889 \mathrm{bp} \\
\text { (AY950802) }\end{array}$ & Spherolipoviridae & $1.1 \times 10^{-11}$ & $\sim 6$ & Lysis & $1.5 \times 10^{11}$ & $\begin{array}{l}{[27,30,31]} \\
\text { This study }\end{array}$ \\
\hline HHTV-1 & $\begin{array}{l}\text { Icosahedral } \\
\text { tailed }\end{array}$ & No lipids & $\begin{array}{c}49,107 \mathrm{bp} \\
(\mathrm{KC} 292025)\end{array}$ & $\begin{array}{l}\text { Unclassified } \\
\text { siphovirus }\end{array}$ & $2.9 \times 10^{-13}$ & $\sim 7$ & Lysis & $7 \times 10^{10}$ & $\begin{array}{c}{[29,38]} \\
\text { This study }\end{array}$ \\
\hline His1 & Spindle-shaped & $\begin{array}{l}\text { Lipid } \\
\text { modified } \\
\mathrm{MCP}^{2}\end{array}$ & $\begin{array}{l}\text { 14,462 bp } \\
\text { (AF191796) }\end{array}$ & $\begin{array}{c}\text { Salterprovirus } \\
\text { genus }\end{array}$ & $1.9 \times 10^{-12}$ & $\sim 4$ & No lysis & $3 \times 10^{10}$ & $\begin{array}{c}{[24,28]} \\
\text { This study }\end{array}$ \\
\hline His2 & Pleomorphic & $\begin{array}{l}\text { Membrane } \\
\text { envelope }\end{array}$ & $\begin{array}{l}16,067 \mathrm{bp} \\
\text { (AF191797) }\end{array}$ & "Pleolipoviridae" & $5.0 \times 10^{-12}$ & $\sim 4$ & No lysis & $5 \times 10^{11}$ & $\begin{array}{l}{[23,28]} \\
\text { This study }\end{array}$ \\
\hline
\end{tabular}

${ }^{1}$ Membrane or lipids in the virion; ${ }^{2} \mathrm{MCP}$, major capsid protein; ${ }^{3}$ Linear dsDNA molecules; ${ }^{4}$ International Committee on Taxonomy of Viruses (ICTV); ${ }^{5}$ Unassigned family. 
The icosahedral tailed virus HHTV-1 morphologically resembles phages of the Siphoviridae family (order Caudovirales) [29] and is the least studied of the Har. hispanica viruses included here (Table 1). Its genome architecture is mosaic, like those of the siphoviruses, a group whose genomes also display a high degree of sequence diversity [38-40]. Its life cycle is unexplored, but it adsorbs slowly to Har. hispanica [29]. As typical for halophilic siphoviruses, HHTV-1 has a very narrow host range; it is known to infect only its isolation host Har. hispanica and its close relative Haloarcula sp. PV7 [41].

The only described euryarchaeal spindle-shaped virus, His1, resembles the short-tailed, spindle-shaped fuselloviruses that infect crenarchaea [24,26,42]. The flexible His1 virion is composed of only one major capsid protein (MCP) species; that MCP is lipid-modified, but the virion lacks a lipid bilayer $[24,43]$. The spindle-shaped virion transforms into a tube that most probably facilitates DNA delivery during infection [43,44]. His1 infection leads to constant virus release without cell lysis and with no retardation of cell growth in culture until the late logarithmic stage [24,28]. Thin-section TEM of infected cells has not yet captured the exiting of any progeny His1 virions [24].

Although His2 virus had been previously suggested to be spindle-shaped [28], it was later found to be one of the pleomorphic archaeal viruses. These viruses have a very simple virion architecture. The chromosome is surrounded by a membrane vesicle containing but a few major protein species [23]. This unique group was recently proposed to form a new viral family, the "Pleolipoviridae" [45]. During virion assembly His2 acquires its lipids non-selectively from the host cell membrane, probably as the virions exit the cell by budding. Virion production slows host growth [23]. His2, like most of the other archaeal pleomorphic viruses, is specific to a single host [23,28].

Typically insights into virion exit strategies can be gained by one-step growth experiments that include measurement of culture turbidity and counts of progeny viruses and viable cells, supplemented with thin section TEM. However, the slow and sometimes inefficient binding of halophilic viruses to their cellular receptor molecules, long host cell generation times, and non-synchronous virus egress make the determination of archaeal virus exit strategies challenging. The literature holds contradictory proposals concerning the release mechanisms used by some halophilic archaeal viruses $[28,31,46,47]$ showing that the traditional metrics are not always sufficient to warrant the conclusions drawn. Here, we investigated the mechanisms employed by four diverse haloarchaeal viruses by monitoring not only host culture turbidity and progeny virus production, but also changes in the euryarchaeal cell envelope during virus exit. The latter was assessed by measuring the concentration of phenyldicarbaundecaborane anion $\left(\mathrm{PCB}^{-}\right)$and the level of dissolved oxygen in the medium [48]. These data were accompanied by tracking intra- and extracellular ATP changes [48]. While this potentiometric approach has been previously used to study the life cycles of several phages in moderate environments [48-53], here we demonstrate that these techniques can also be applied to viruses thriving in extreme salinities $(>3 \mathrm{M} \mathrm{NaCl})$.

\section{Materials and Methods}

\subsection{Cells, Viruses and Growth of Viruses}

In this study, we investigated Har. hispanica [25] and four of its viruses: SH1 [31], HHTV-1 [29], His1, and His2 [26] (Table 1). Cultures were grown aerobically at $37^{\circ} \mathrm{C}$ in modified growth medium (MGM) containing artificial salt water (SW) (for details, see [54,55]). Broth, solid, and soft-agar media contained $23 \%, 20 \%$, and $18 \% \mathrm{SW}$, respectively. For virus production, suitable virus dilutions were used to obtain semi-confluent plates. To avoid drying during culture, a cup of water was placed with the plates in closed plastic boxes. The soft agar layer of the semiconfluent plates was collected, mixed with $2 \mathrm{~mL}$ of MGM per plate, and the resulting suspension was incubated with shaking for $2 \mathrm{~h}$ at $37^{\circ} \mathrm{C}$. Soft agar and cell debris were removed by centrifugation (Sorvall SA600 rotor, $9500 \mathrm{rpm}, 20 \mathrm{~min}$, $+4{ }^{\circ} \mathrm{C}$ ). The supernatant (virus stock) was stored at $+4{ }^{\circ} \mathrm{C}$. Virus titers $(\mathrm{pfu} / \mathrm{mL}$ ) were determined by plaque assay [56]. Culture turbidity was monitored $\left(\mathrm{A}_{550}\right)$, and viable cell counts $(\mathrm{cfu} / \mathrm{mL})$ were measured when appropriate. Cells were disrupted by incubation in boiling water for $5 \mathrm{~min}$. 


\subsection{Adsorption Assay}

The adsorption rate constant of His2 was determined by infecting Har. hispanica culture $\left(\sim 1 \times 10^{9} \mathrm{cfu} / \mathrm{mL}\right)$ with His2 virus stock using a multiplicity of infection (MOI) of $\sim 1 \times 10^{-4}$. MGM medium without cells was used as a control. The mixtures were incubated at $+37^{\circ} \mathrm{C}$ with aeration. Samples taken at different time points were diluted 1:100 in MGM broth. The cells were removed by centrifugation (Biofuge table centrifuge, $13,000 \mathrm{rpm}, 5 \mathrm{~min},+20^{\circ} \mathrm{C}$ ) and the number of free viruses in the supernatant was determined by plaque assay. The adsorption rate constant $(k)$ was calculated using the formula $k=2.3 \times \log \left(P_{0} / P\right) /(B) t$, where $B$ is the cell concentration, $P_{0}$ is the concentration of free viruses at the beginning, $P$ is the concentration of free viruses at the end, and $t$ is the period of time [56].

\subsection{On-Line Electrochemical Measurements during Virus Infection}

Har. hispanica cells grown in flask culture to $5 \times 10^{8} \mathrm{cfu} / \mathrm{mL}\left(\mathrm{A}_{550}\right.$ of 1$)$ were infected using the virus stock to give an MOI of 20. For the uninfected control, the same volume of MGM medium was substituted for the virus stock. Cultures were incubated for $2 \mathrm{~h}$, and then the unadsorbed viruses were removed by collecting the cells by centrifugation (Sorvall SA600 rotor, $5000 \mathrm{rpm}, 10 \mathrm{~min},+20^{\circ} \mathrm{C}$ ). The cells were resuspended in preheated $\operatorname{MGM}\left(+37^{\circ} \mathrm{C}\right)$ to yield a six-fold concentrated cell suspension and transferred immediately into the $50 \mathrm{~mL}$ reaction vessels for measurements. Growth of the cells continued in the reaction vessels $\left(37^{\circ} \mathrm{C}\right)$ covered with aluminum foil to prevent evaporation. Turbidity $\left(\mathrm{A}_{550}\right)$ was always followed during growth and electrochemical measurements in the vessels. Number of progeny viruses was determined by plaque assay starting $4 \mathrm{~h}$ p.i. To determine the concentration of phenyldicarbaundecaborane $\left(\mathrm{PCB}^{-}\right)$in the medium, the amount of dissolved oxygen and the ATP content (see Section 2.4), the uninfected and infected cells were grown in the vessels. For $\mathrm{PCB}^{-}$ measurements, before adding the cells the electrode was calibrated by adding $\mathrm{PCB}^{-}$to the medium to the final concentration of $3 \mu \mathrm{M}$.

The concentration of $\mathrm{PCB}^{-}$was determined using selective electrodes either prepared as previously described $[57,58]$ or as defined below. To synthetize $\mathrm{PCB}^{-}$sensitive membranes, we tested different plasticizers (2-nitrophenyl octyl ether, NPOE (Sigma, St. Louis, MO, USA); dioctyl phthalate (Fluka, Buchs, Switzerland); dibutyl phthalate (Sigma) [59]), concentrations of poly-vinyl chloride $(\mathrm{PVC} ; 6 \%, 10 \%(w / v))$, and concentrations of $\mathrm{PCB}^{-}(0.25 \mathrm{mM}$ and $0.1 \mathrm{mM})$. In addition, membrane thickness as well as electrode regeneration and storage conditions were optimized. Electrodes were prepared at room temperature. The final solution for membrane synthesis consisted of diluent tetrahydrofuran (THF; Fluka), 6\% ( $w / v)$ PVC (Aldrich, St. Louis, MO, USA), $270 \mathrm{mM}$ plasticizer $\mathrm{NPOE}$, and the ion pair of $\mathrm{PCB}^{-}(0.05 \mathrm{mM})$ with tetraphenylphosphonium $\left(0.05 \mathrm{mM} \mathrm{TPP}{ }^{+}\right.$; Sigma). The potassium salt of $\mathrm{PCB}^{-}$was provided by Aldona Beganskiene, Department of Inorganic Chemistry, Vilnius University. A tip of the glass tube (inner diameter of $0.6 \mathrm{~cm}$ and length of $5.5 \mathrm{~cm}$, Laborexin, Helsinki, Finland) was immersed into the membrane synthesis solution to obtain a thin film, which was dried at room temperature. The immersion was repeated once. After drying of the membrane, the final thickness of the coating was obtained by casting three thin layers of the membrane synthesizing solution ( $45 \mu \mathrm{L}$ each) on the film (inside the tube). Before each measurement the membrane was soaked in $1 \mathrm{mM} \mathrm{PCB}^{-}$(in distilled water) for $12 \mathrm{~h}$ and then in $1 \mu \mathrm{M} \mathrm{PCB}^{-}$for $24 \mathrm{~h}$. For longer periods of storage, the membranes were dried and stored at room temperature. The glass tube with a membrane was filled with a solution of $1 \mathrm{mM} \mathrm{PCB}^{-}$in $150 \mathrm{mM} \mathrm{NaCl}$, and then attached to the $\mathrm{Ag}$ - $\mathrm{AgCl}$ half-cell electrode. The Ag-AgCl reference electrode (Thermo, St. Louis, MO, USA, Orion S/junction) was indirectly connected to the reaction vessel through an agar salt bridge.

A selective electrode (Thermo, Orion 97-08 electrode) was used to determine on-line the amount of dissolved oxygen in the medium [48]. Solid $\mathrm{Na}_{2} \mathrm{~S}_{2} \mathrm{O}_{5}$ was added to deplete oxygen to obtain the zero base line $(0 \%)$. The maximum dissolved oxygen $(100 \%)$ was registered before adding the cells to the aerated medium. 
For data collection, the electrodes were connected to potential amplifying system with an ultralow input bias current operational amplifier AD549JH (Analog Devices, Norwood, MA, USA). The signal amplifier was connected to a computer through data acquisition system PowerLab 8/35 (ADInstruments, Oxford, UK).

\subsection{ATP Measurements during Virus Infection}

To measure intra- and extracellular ATP content, $110 \mu \mathrm{L}$ samples were taken from the reaction vessels (see above) and the cells collected by centrifugation (Biofuge table centrifuge, $5 \mathrm{~min}, 13,000 \mathrm{rpm}$, $+25^{\circ} \mathrm{C}$ ). The supernatant was kept and the pellets were resuspended into the original volume of MGM. Twenty-five microliter samples were withdrawn from the $110 \mu \mathrm{L}$ samples of both the supernatant and the pellet fractions and the ATP contents were measured using the ATP Biomass Kit (BioThema, Handen, Sweden) and the Turner BioSystems 20/20 luminometer (Promega, Sunnyvale, CA, USA) with two injectors. During all measurements the volumes of the sample, Extractant (BioThema) and luciferin/luciferase reagent (ATP Reagent; BioThema) were $25 \mu \mathrm{L}, 25 \mu \mathrm{L}$, and $100 \mu \mathrm{L}$, respectively. To measure the amount of ATP the extractant and ATP reagent were injected three seconds after the sample was taken. The light emissions of the extracellular and intracellular ATP were measured after 10 and $150 \mathrm{~s}$ (to ensure that cell envelope was destroyed), respectively. For calibration, $25 \mu \mathrm{L}$ of ATP standard $(100 \mathrm{nM})$ was measured as the extracellular ATP.

\section{Results}

\subsection{Adsorption Rate Constant of Pleomorphic Virus His2 to Har. hispanica}

The adsorption rate constants for SH1, HHTV-1, and His1 have been previously determined (Table 1) $[24,29,30]$. The adsorption rate of His2 was determined here by mixing viruses and host cells at low MOI and determining the reduction in the unadsorbed virus fraction by plaque assay. No reduction in the plaque number in the control (without the cells) was detected. At $2.5 \mathrm{~h} \mathrm{p.i.,} 50 \%$ of the viruses were adsorbed (Figure 1). The slight increase in the number of unadsorbed viruses $3 \mathrm{~h}$ p.i. was due to the release of progeny viruses. The adsorption rate constant calculated for His 2 based on the initial $2 \mathrm{~h}$ adsorption period was $5.0 \times 10^{-12} \mathrm{~mL} / \mathrm{min}$ (Table 1 ).

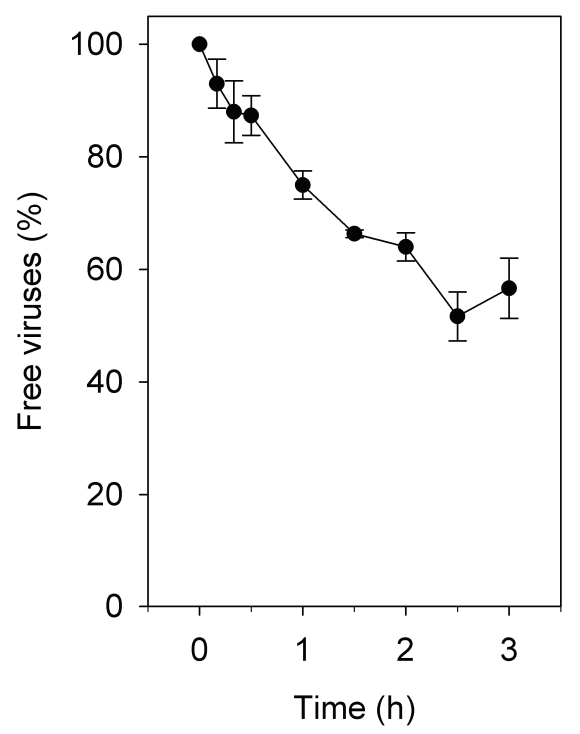

Figure 1. Adsorption efficiency of His2 to Haloarcula hispanica cells at $37^{\circ} \mathrm{C}$ with aeration. The number of unadsorbed viruses was determined by plaque assay. Linear regression was calculated for 0-150 $\mathrm{min}$ $\left(r^{2}=0.97\right)$. The last point $(180 \mathrm{~min})$ shows the effect of release of the first progeny viruses (see also Figure 3D). 


\subsection{Monitoring the Turbidity and Counts of Viable Cells and Progeny Viruses during Virus Production}

We monitored infected and uninfected Har. hispanica cell cultures by measuring the culture turbidity, as well as the number of both progeny viruses and viable cells. At $25 \mathrm{~h}$ p.i., the uninfected culture reached a turbidity of $\sim 1.4\left(\mathrm{~A}_{550}\right)$ and a viable cell count of $\sim 2 \times 10^{9} \mathrm{cfu} / \mathrm{mL}$ (Figures 2A,D and 3A,D).

Following SH1 infection, the decrease in culture turbidity and virus release both started at $6 \mathrm{~h}$ p.i. (Figure $2 \mathrm{~A}$ ). At $25 \mathrm{~h}$ p.i., the turbidity was $\sim 0.6\left(\mathrm{~A}_{550}\right)$, the viable cell count was reduced to $\sim 1 / 1000$, and the number of infectious progeny viruses had reached $\sim 2 \times 10^{11} \mathrm{pfu} / \mathrm{mL}$ (Figure $2 \mathrm{~A}$ ). The lifecycle of HHTV-1 proceeded similarly, except that virus production increased later, at $7 \mathrm{~h}$ p.i. and the final virus titer was $\sim 7.5 \times 10^{10} \mathrm{pfu} / \mathrm{mL}$ (Figure $2 \mathrm{D}$ ).

\section{$\mathrm{SH} 1$}

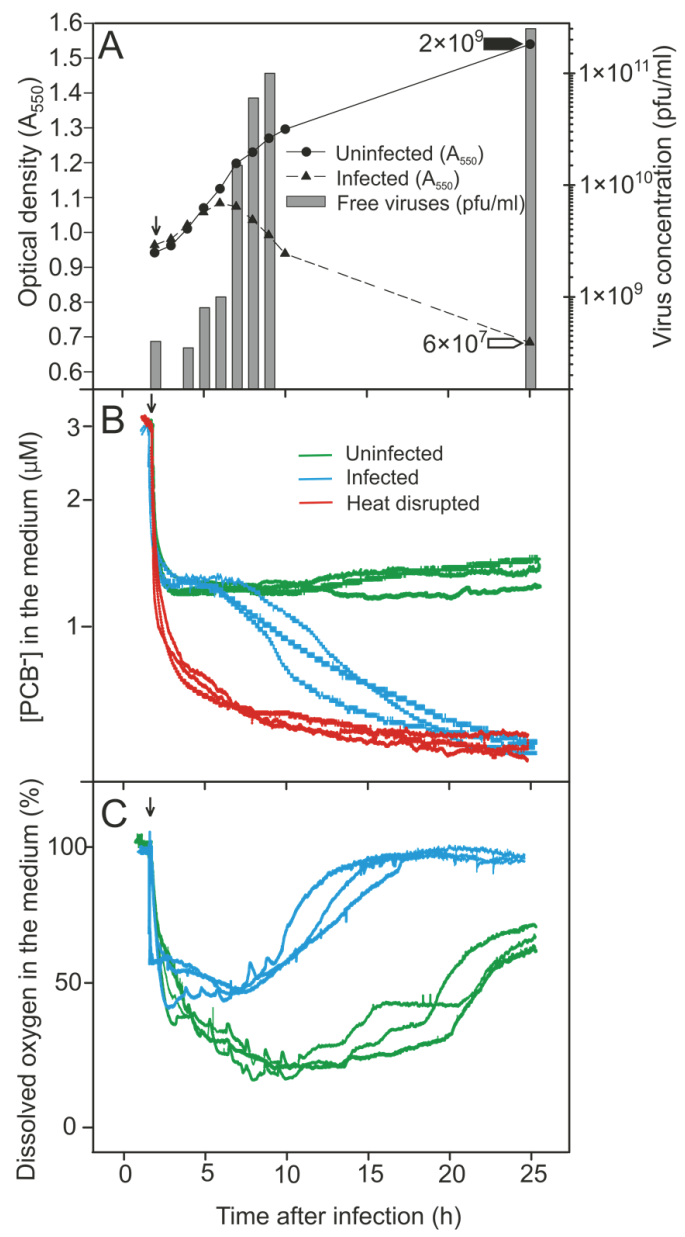

\section{HHTV-1}

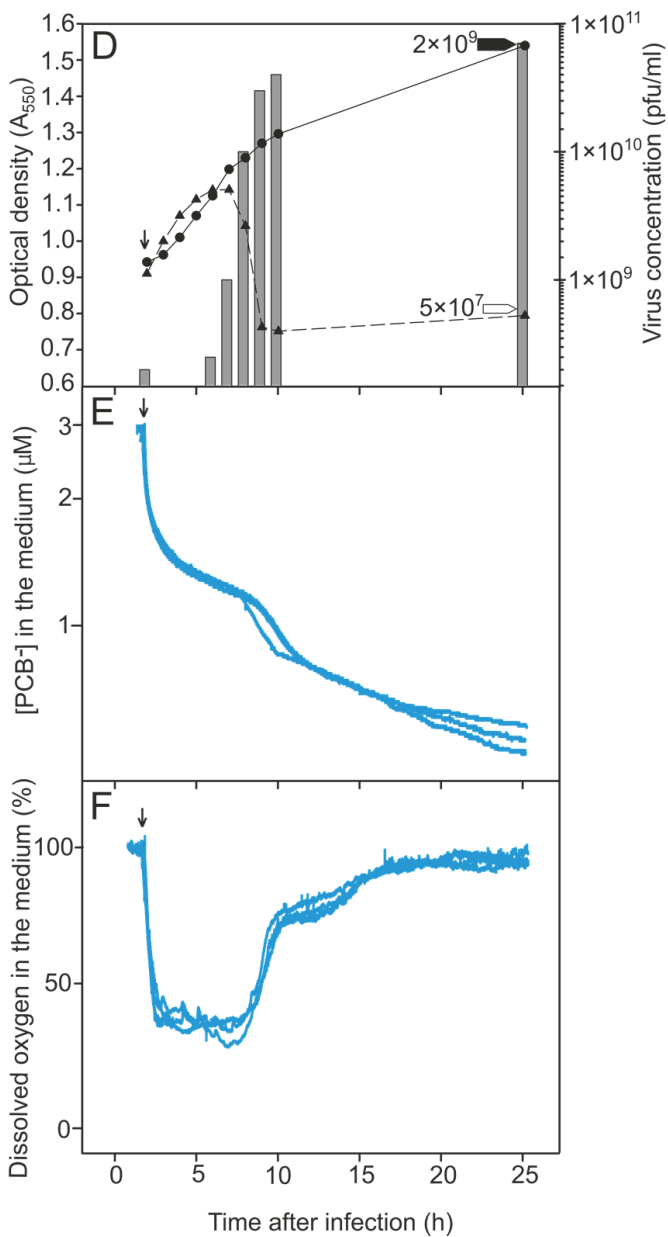

Figure 2. Growth parameters and physiological changes in Haloarcula hispanica during infection by (A-C) SH1 and (D,F) HHTV-1 (MOI of 20). Unadsorbed viruses were removed at $2 \mathrm{~h}$ p.i. and measurements were begun at $2 \mathrm{~h} 15 \mathrm{~min}$ p.i. (indicated by arrows) and were carried out in MGM medium at $37^{\circ} \mathrm{C}$ with aeration. (A,D) Turbidities of the infected and uninfected cultures; the number of free progeny viruses $(\mathrm{pfu} / \mathrm{mL})$ in the infected cultures; and the number of viable cells $(\mathrm{cfu} / \mathrm{mL})$ at $25 \mathrm{~h}$ p.i. in the uninfected (black arrow head) and infected cultures (white arrow head); (B,E) $\mathrm{PCB}^{-}$binding in the presence of $\mathrm{PCB}^{-}$(calibrated with $3 \mu \mathrm{M} \mathrm{PCB}^{-}$) to infected, uninfected, and heat disrupted (showing the maximal binding) Har. hispanica cells $(n=3) ;(\mathbf{C}, \mathbf{F})$ The level of dissolved oxygen in the medium of infected and uninfected Har. hispanica cells $(n=3)$. 
His1

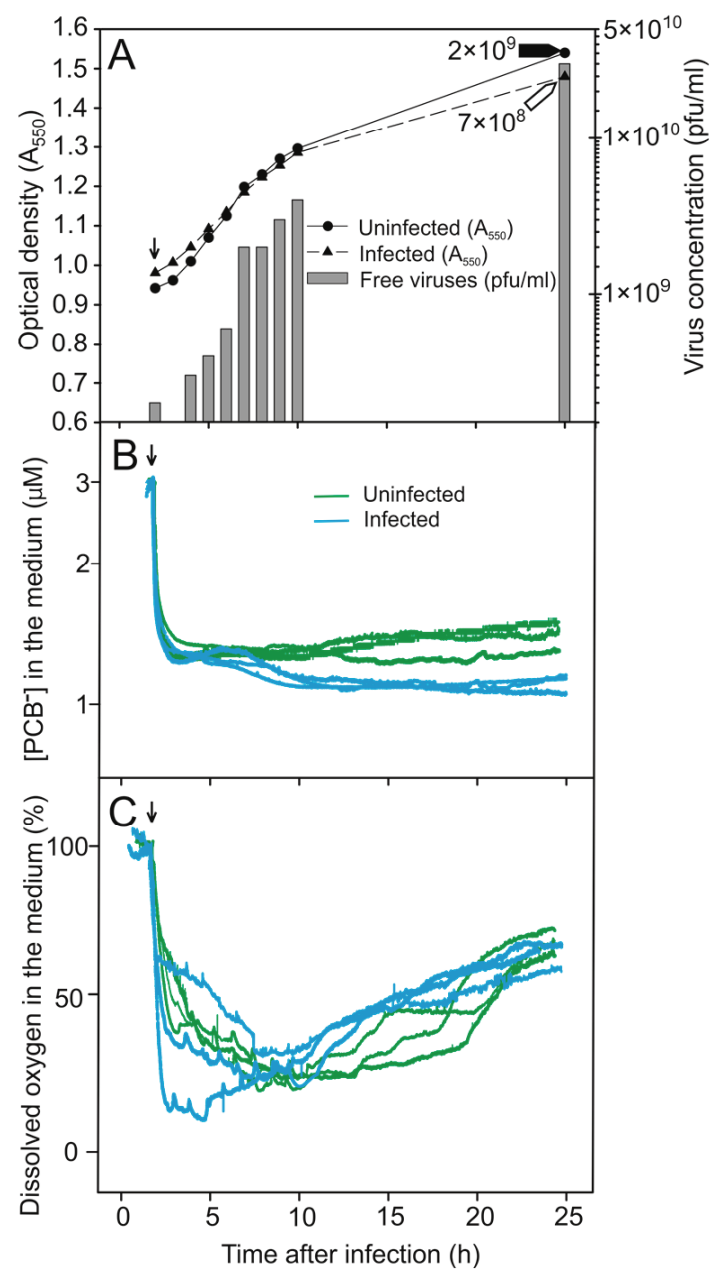

\section{His2}

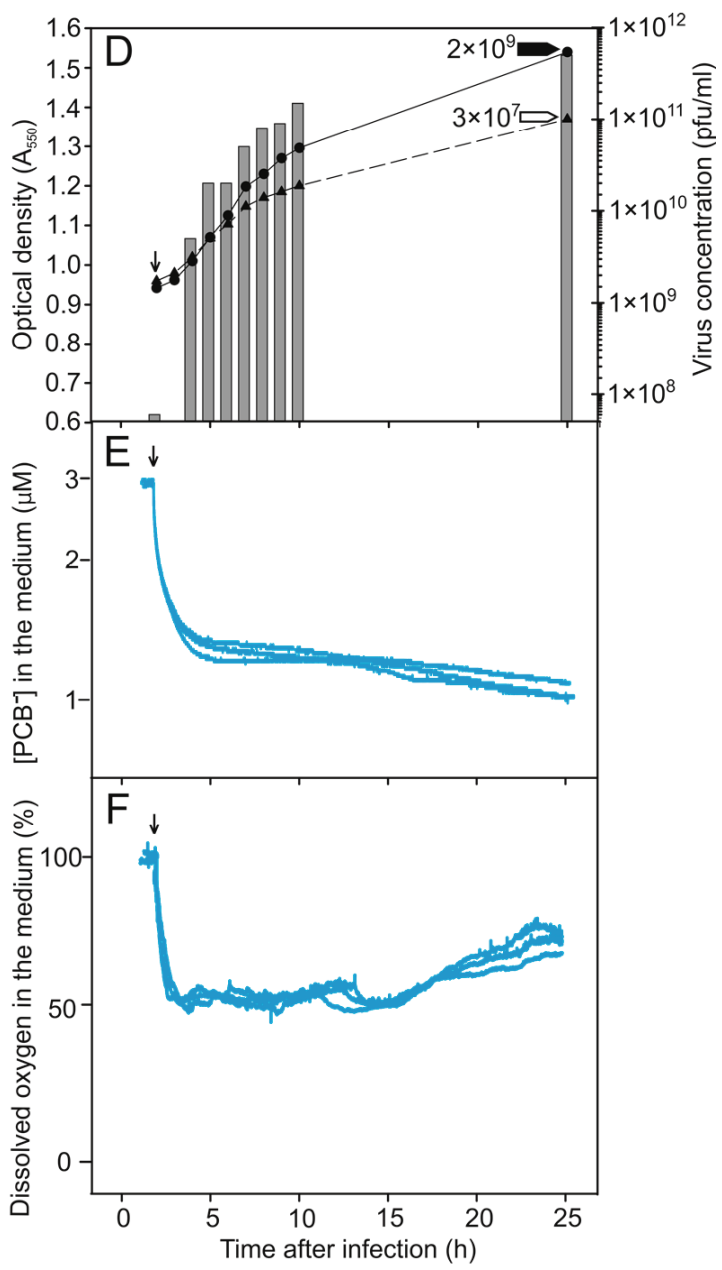

Figure 3. Growth parameters and physiological changes in Haloarcula hispanica during (A-C) His1 and $(\mathrm{D}, \mathrm{F})$ His2 virus infection (MOI of 20). For $\mathrm{PBC}^{-}$binding and oxygen consumption for the uninfected and heat disrupted control cells, see Figure 2A-C.

In the case of His1, the turbidities of the infected and uninfected Har. hispanica cultures did not show any significant differences, and at $25 \mathrm{~h}$ p.i., the number of viable cells in both cultures were practically the same $\left(\sim 7 \times 10^{8}\right.$ and $\left.\sim 2 \times 10^{9} \mathrm{cfu} / \mathrm{mL}\right)$. Exit of the progeny His1 viruses started 3 to $4 \mathrm{~h}$ p.i., and the number of infectious viruses reached $\sim 3 \times 10^{10} \mathrm{pfu} / \mathrm{mL}$ at $25 \mathrm{~h}$ p.i. (Figure $3 \mathrm{~A}$ ).

The progeny His2 viruses appeared 3 to $4 \mathrm{~h}$ p.i. and caused cell growth retardation (Figure 3D). At $25 \mathrm{~h}$ p.i., the number of infectious progeny viruses was high $\left(\sim 5 \times 10^{11} \mathrm{pfu} / \mathrm{mL}\right)$. At the same time, the difference in the numbers of viable cells in the infected and uninfected cultures was around two orders of magnitude $\left(\sim 2 \times 10^{9}\right.$ vs. $\sim 3 \times 10^{7} \mathrm{cfu} / \mathrm{mL}$; Figure 3D). Based on culture turbidity data (and see also below), neither His1 nor His2 caused any detectable cell lysis during virus release, whereas SH1 and HHTV-1 clearly caused lysis of Har. hispanica cells. 


\subsection{Binding of $\mathrm{PCB}^{-}$to Har. hispanica Cells as an Indicator of the Start of Lytic Virus Release}

The $\mathrm{PCB}^{-}$anion can be effectively used as an indicator of the integrity of the cell envelope as it binds to exposed phospholipid bilayers $[48,57,58]$. To measure the binding of $\mathrm{PCB}^{-}$, the uninfected and infected cells were grown in MGM medium $(\sim 3 \mathrm{M} \mathrm{NaCl})$ supplemented with $\mathrm{PCB}^{-}(3 \mu \mathrm{M})$. When the cells were added to the vessels to start the measurements, decrease of $\mathrm{PCB}^{-}$concentration in the medium was observed as a consequence of unspecific binding of this indicator by the culture components defining the background level (Figure 2B). The presence of $\mathrm{PCB}^{-}$in the growth medium decreased the Har. hispanica growth rate only slightly during the exponential growth phase and had no effect on progeny production for all four viruses. Both electrodes (see Materials and Methods) gave the same reproducible signal. Maximum binding of $\mathrm{PCB}^{-}$occurred with heat disrupted cells, a treatment that reduced the number of viable cells $\sim 3.5$ orders of magnitude (Figure $2 \mathrm{~B}$ ). When monitoring binding during the infection cycle, once equilibrium had been reached, the cells did not bind further $\mathrm{PCB}^{-}$ (Figures 2B,E and 3B,E).

During SH1 infection, a change in $\mathrm{PCB}^{-}$binding started at $6 \mathrm{~h}$ p.i., the same time as the start of virus release (Figure $2 \mathrm{~A}, \mathrm{~B}$ ). Similar strong binding of $\mathrm{PCB}^{-}$was observed during HHTV-1 infection but starting at $7 \mathrm{~h}$ p.i., which also was simultaneous with the initial virus release (Figure 2D,E). However, during His1 and His2 virus production and release, minimal increase in $\mathrm{PCB}^{-}$binding was observed in spite of the high number of viruses released (Figure $3 A, B, D, E$ ).

\subsection{Changes in the Levels of Oxygen Consumption during Virus Infection}

For aerobic organisms, the level of oxygen consumption is a universal measure of the physiological state of the cell. This parameter was assessed by measuring the amount of oxygen dissolved in the medium of infected and uninfected cell cultures. The defined aeration rate used provided sufficient oxygen to sustain the exponential growth rate while also maintaining the oxygen level within a quantifiable range. When the cells were added to the reaction vessel (Figure $2 \mathrm{C}$, arrow), consumption of oxygen started immediately and the amount of dissolved oxygen in the medium decreased rapidly until it reached the balance. As uninfected Har. hispanica cells entered stationary phase ( 10 h p.i.), their oxygen consumption declined, resulting in first a steady and then an increasing level of oxygen in the medium (Figure 2C). During SH1 infection, oxygen consumption by Har. hispanica cells peaked at $6 \mathrm{~h}$ p.i., simultaneous with increase of the progeny SH1 virus particles (Figure 2C). After that the registered oxygen level in the medium increased significantly indicating cell death. Similarly, oxygen consumption by the HHTV-1 infected culture decreased starting at $7 \mathrm{~h}$ p.i., concurrent with the peak virus production (Figure $2 \mathrm{~F}$ ). In contrast, the production of His1 viruses did not affect oxygen consumption by the host cells (Figure 3C). In the case of His2, a comparable trend was observed, i.e., no change in the oxygen level was evident during virus release, but the infected cells consumed less oxygen than the uninfected ones (Figure 3F). This correlates with the growth rate retardation and the resulting reduced number of viable cells in His2 infected cultures (Figure 3D,F).

\subsection{Changes in the Concentration of Intracellular and Extracellular ATP during Virus Infection}

ATP content of Har. hispanica cells and ATP leakage from the cells into the medium were measured during the first $10 \mathrm{~h}$ following infection with each of the four haloarchaeal viruses (Figure 4). For uninfected Har. hispanica cells, ATP content was growth phase dependent, decreasing in the late logarithmic phase, and ATP leakage was also observed (Figure 4A,B). Both SH1 and HHTV-1 caused strong leakage of ATP at the time of virus production (Figure 4C-F). Following infection with His1 or His2 (Figure 4G-J), the ATP levels resembled those for uninfected Har. hispanica cells (Figure 4B) with no indication of ATP leakage to the extracellular medium. 


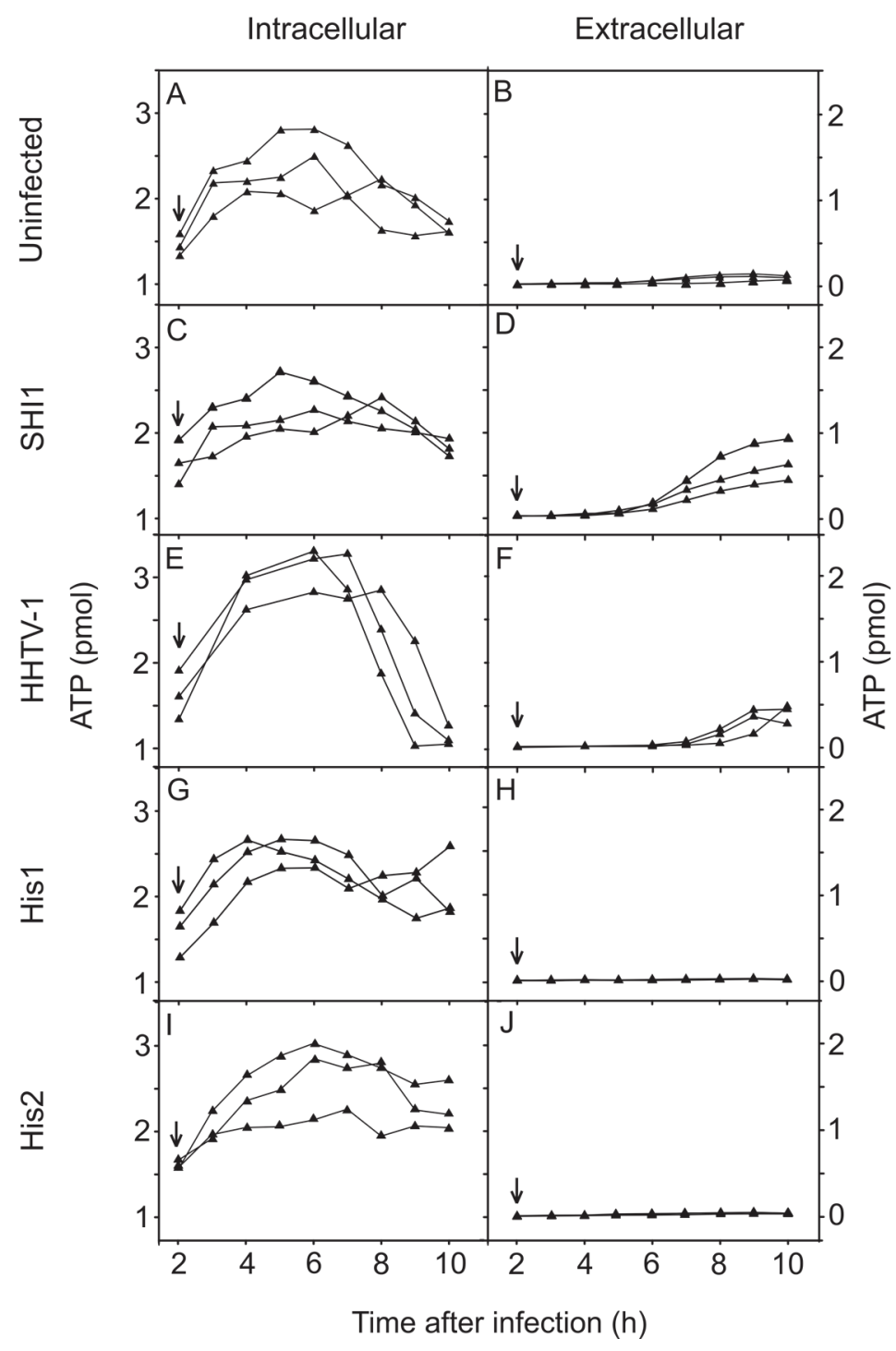

Figure 4. The amount of the intracellular and extracellular ATP in uninfected and virus-infected (MOI of 20) cultures. Unadsorbed viruses were removed at $2 \mathrm{~h}$ p.i. and measurements $(n=3)$ were started at $2 \mathrm{~h} 15 \mathrm{~min}$ p.i. (marked by arrows).

\section{Discussion}

The first archaeal virus was discovered in 1974 [4], although Archaea was not recognized as a separate domain until the late 1970s [60]. Since then, the uniqueness of archaeal viruses and their ability to flourish in extreme environments has inspired researchers to also investigate their interplay with their host cells. The recent isolation of more archaeal viruses $[5,6]$ has offered the possibility of new archaeal virus-host model systems. Nevertheless, the limited set—or complete lack—of genetic tools to manipulate archaeal viruses, e.g., suppression [61-63], and the extreme conditions required for their propagation pose significant challenges. Consequently, our knowledge of archaeal virus life cycles is nearly non-existent.

It has been thought for phages that their comparatively early and synchronous lysis reflects their rapid adsorption [64]. Even in high salinity environments, the phages have higher adsorption rates than the haloarchaeal viruses present $[29,65]$. Pleomorphic virus His2 was found in this study to bind slowly to Har. hispanica cells with an adsorption rate constant of $5.0 \times 10^{-12} \mathrm{~mL} / \mathrm{min}$ (Figure 1). This rate is comparable to those of the other three Har. hispanica viruses included in this study: 
icosahedral membrane-containing virus $\mathrm{SH} 1$, spindle-shaped virus His1, and icosahedral tailed virus HHTV-1 $\left(1.1 \times 10^{-11}\right.$ to $2.9 \times 10^{-13} \mathrm{~mL} / \mathrm{min}$; Table 1$)[24,29,30]$. However, it is considerably slower than the rate for the pleomorphic virus HHPV-1 of Har. hispanica $\left(2.0 \times 10^{-10} \mathrm{~mL} / \mathrm{min}\right.$ [29] $)$. By having an adsorption rate constant comparable to that of phages, HHPV-1 demonstrates that not all halophilic archaeal viruses are slow binders [29].

Haloarchaeal virulent viruses are often released slowly and nonsynchronously $[31,32,66]$. Due to the differences between the cell envelopes of archaea and bacteria [3], the lysis mechanisms of archaeal viruses most probably do not mimic those known for phages $[67,68]$. Indeed, the pyramid structures induced in the archaeal cell envelopes have been observed only during egress of the crenarchaeal viruses STIV and SIRV2 $[9,10]$. However, so far no other mechanism for virus-induced disruption of archaeal membranes has been proposed. The slow adsorption rate of these viruses can explain their non-synchronous release by cell lysis. For slowly binding viruses such as SH1 (Table 1), their virus release can be easily misinterpreted as occurring without lysis $[9,10]$. Consequently, measurement of the infected culture turbidity alone cannot always detect the lytic exit of archaeal viruses. This is also the case for archaeal viruses that use the pyramid exit mechanism due to the creation of empty ghost cells $[9,10]$. To avoid this pitfall, we took advantage of electrochemical techniques to probe the changes in the integrity of the euryarchaeal cell membrane during virus production and egress and to detect the changes in oxygen consumption. This work represents the first application of this approach to the haloarchaea and their viruses that thrive in high salinity (over $3 \mathrm{M} \mathrm{NaCl}$ ). We used previously prepared $\mathrm{PCB}^{-}$electrodes, but also developed a new, convenient method to construct $\mathrm{PCB}^{-}$selective electrodes (see Material and Methods). Thus, by observing the impact of archaeal virus infections on the physiological state of Har. hispanica cells during virus progeny production, we could determine unambiguously whether or not the virus exit was accompanied by membrane disruption (Figures 2 and 3).

Here we demonstrated that the SH1 virus life cycle ends with the lysis of the Har. hispanica host cells and the resultant release of progeny viruses (Figure 2A-C), as had been previously shown [31,47] although other exit strategies had also been proposed [46]. Cell lysis was indicated not only by the drop in the culture turbidity concomitant with progeny virus release, but also by the strong increased binding by $\mathrm{PCB}^{-}$and reduction in oxygen consumption. Moreover, ATP leakage from the cells is in line with these metrics (Figure 4C,D). In the same way, HHTV-1 caused cell lysis during its exit (3 h; Figure 2D,F). During cell lysis, less ATP leaked into the medium than was depleted inside the cells (Figure 4E-F). This led us to hypothesize that part of intracellular ATP was used for other processes related to virus assembly, for example virus genome packaging that requires energy in the form of ATP [69].

Comparison of SH1 and HHTV-1 virus release to that of His1 and His2 highlighted a clear difference in their mechanisms of virus exit. Instead of cell lysis, His1 and His2 progeny viruses were released without apparent cell membrane damage. Previously, it has been shown that His1 does not lyse cells, but can also retard cell growth during virus egress [24,28]. Throughout the infection, oxygen consumption stayed at the same level as in the uninfected culture. The host membrane was inaccessible to the $\mathrm{PCB}^{-}$indicator ion showing that the cell envelope was intact (Figure 3E). In addition, the lack of detectable ATP leakage supports the conclusion that His1 is a non-lytic virus. We hypothesize that His1 buds out from the euryarchaeal cell. During His2 release, the turbidity of the infected culture did not decrease, but host growth was retarded in the late logarithmic growth phase (Figure 3D), as had been previously noticed [23,28]. In addition, during His2 infection, cells used less oxygen than other infected ones (Figures 2C,F and 3C,F) suggesting that that His2 infected cells are more compromised than the other cells. Consequently, the number of viable cells that could make a colony on a plate is lower than expected based on turbidity of the culture. We also observed weak $\mathrm{PCB}^{-}$binding at about $12 \mathrm{~h}$ p.i., during the late logarithmic growth phase, but we do not attribute this to virus exit induced cell membrane rupture for two reasons: first, at that time the major virus exit was almost finished; second, no ATP leakage was detected during the first $10 \mathrm{~h}$ of infection. The number of His2 
viruses released into the medium is high (over $1 \times 10^{11} \mathrm{pfu} / \mathrm{mL}$ at $10 \mathrm{~h}$ p.i.). That the presence of these abundant membrane-containing virions does not induce $\mathrm{PCB}^{-}$binding also shows that the intact virus membranes in the infectious virions are inaccessible to the indicator ion and consequently the $\mathrm{PCB}^{-}$ binding registered is a consequence of ruptured cell membranes (Figure 3E). These results demonstrate that viruses His1 and His2 are not released by cell lysis. We envision that these methods can be applied to other archaeal virus systems as well, and thereby help clarify the mechanisms of archaeal virus release from their host cells.

\section{Conclusions}

The monitoring of membrane-associated parameters enabled us to clearly distinguish virus egress by cell lysis from exit without disruption of the cellular membrane. Our results indicated that SH1 and HHTV-1 lysed their host cell, whereas the release mechanism of His1 and His2 is non-lytic.

Acknowledgments: This study was supported by Academy Professor (Academy of Finland) funding grants 283072 and 255342 (Dennis H. Bamford) and by VMU grant No P-BF-13-06 (Rimantas Daugelavičius). The authors acknowledge the support of employees and the use of experimental resources of Instruct. We thank Academy of Finland (funding grant 272853) and University of Helsinki for the support to EU ESFRI Instruct Centre for Virus Production (ICVIR) used in this study. Julija Svirskaite is a fellow of the Doctoral Program in Microbiology and Biotechnology, University of Helsinki. This study was supported by the LLP Erasmus Internship Programme (2013). We thank Sigita Pangonytè for assistance.

Author Contributions: Julija Svirskaitè, Hanna M. Oksanen and Dennis H. Bamford conceived and designed the experiments; Julija Svirskaite performed the experiments; Julija Svirskaitè, Hanna M. Oksanen, Rimantas Daugelavičius and Dennis H. Bamford analyzed the data; Julija Svirskaitė, Rimantas Daugelavičius and Dennis H. Bamford contributed reagents/materials/analysis tools; and Julija Svirskaitè, Hanna M. Oksanen, Rimantas Daugelavičius and Dennis H. Bamford wrote the paper.

Conflicts of Interest: The authors declare no conflict of interest.

\section{References}

1. DeLong, E.F. Everything in moderation: Archaea as "non-extremophiles". Curr. Opin. Genet. Dev. 1998, 8, 649-654. [CrossRef]

2. Sprott, G.D. Structures of archaebacterial membrane lipids. J. Bioenerg. Biomembr. 1992, 24, 555-566. [CrossRef] [PubMed]

3. Albers, S.V.; Meyer, B.H. The archaeal cell envelope. Nat. Rev. Microbiol. 2011, 9, 414-426. [CrossRef] [PubMed]

4. Torsvik, T.; Dundas, I.D. Bacteriophage of Halobacterium salinarium. Nature 1974, 248, 680-681. [CrossRef] [PubMed]

5. Atanasova, N.S.; Bamford, D.H.; Oksanen, H.M. Haloarchaeal virus morphotypes. Biochimie 2015, 118, 333-343. [CrossRef] [PubMed]

6. Pina, M.; Bize, A.; Forterre, P.; Prangishvili, D. The archeoviruses. FEMS Microbiol. Rev. 2011, 35, $1035-1054$. [CrossRef] [PubMed]

7. Prangishvili, D. The wonderful world of archaeal viruses. Annu. Rev. Microbiol. 2013, 67, 565-585. [CrossRef] [PubMed]

8. Quemin, E.R.; Quax, T.E. Archaeal viruses at the cell envelope: Entry and egress. Front. Microbiol. $2015,6$. [CrossRef] [PubMed]

9. Bize, A.; Karlsson, E.A.; Ekefjard, K.; Quax, T.E.; Pina, M.; Prevost, M.C.; Forterre, P.; Tenaillon, O.; Bernander, R.; Prangishvili, D. A unique virus release mechanism in the Archaea. Proc. Natl. Acad. Sci. USA 2009, 106, 11306-11311. [CrossRef] [PubMed]

10. Brumfield, S.K.; Ortmann, A.C.; Ruigrok, V.; Suci, P.; Douglas, T.; Young, M.J. Particle assembly and ultrastructural features associated with replication of the lytic archaeal virus Sulfolobus turreted icosahedral virus. J. Virol. 2009, 83, 5964-5970. [CrossRef] [PubMed]

11. Luo, Y.N.; Pfister, P.; Leisinger, T.; Wasserfallen, A. The genome of archaeal prophage $\Psi$ M100 encodes the lytic enzyme responsible for autolysis of Methanothermobacter wolfeii. J. Bacteriol. 2001, 183, 5788-5792. [CrossRef] [PubMed] 
12. Pfister, P.; Wesserfallen, A.; Stettler, R.; Leisinger, T. Molecular analysis of Methanobacterium phage $\psi \mathrm{M} 2$. Mol. Microbiol. 1998, 30, 233-244. [CrossRef] [PubMed]

13. Saier, M.H., Jr.; Reddy, B.L. Holins in bacteria, eukaryotes, and archaea: Multifunctional xenologues with potential biotechnological and biomedical applications. J. Bacteriol. 2015, 197, 7-17. [CrossRef] [PubMed]

14. Young, R.; Wang, I.N.; Roof, W.D. Phages will out: Strategies of host cell lysis. Trends Microbiol. 2000, 8, 120-128. [CrossRef]

15. Witte, A.; Wanner, G.; Blasi, U.; Halfmann, G.; Szostak, M.; Lubitz, W. Endogenous transmembrane tunnel formation mediated by $\varphi$ X174 lysis protein-E. J. Bacteriol. 1990, 172, 4109-4114. [PubMed]

16. Rakonjac, J.; Feng, J.N.; Model, P. Filamentous phage are released from the bacterial membrane by a two-step mechanism involving a short C-terminal fragment of pIII. J. Mol. Biol. 1999, 289, 1253-1265. [CrossRef] [PubMed]

17. Prangishvili, D. Archaeal viruses: Living fossils of the ancient virosphere? Ann. N. Y. Acad. Sci. 2015, 1341, 35-40. [CrossRef] [PubMed]

18. Zhang, Z.; Liu, Y.; Wang, S.; Yang, D.; Cheng, Y.; Hu, J.; Chen, J.; Mei, Y.; Shen, P.; Bamford, D.H.; et al. Temperate membrane-containing halophilic archaeal virus SNJ1 has a circular dsDNA genome identical to that of plasmid pHH205. Virology 2012, 434, 233-241. [CrossRef] [PubMed]

19. Liu, Y.; Wang, J.; Liu, Y.; Wang, Y.; Zhang, Z.; Oksanen, H.M.; Bamford, D.H.; Chen, X. Identification and characterization of SNJ2, the first temperate pleolipovirus integrating into the genome of the SNJ1-lysogenic archaeal strain. Mol. Microbiol. 2015. [CrossRef] [PubMed]

20. Witte, A.; Baranyi, U.; Klein, R.; Sulzner, M.; Luo, C.; Wanner, G.; Kruger, D.H.; Lubitz, W. Characterization of Natronobacterium magadii phage $\Phi C h 1$, a unique archaeal phage containing DNA and RNA. Mol. Microbiol. 1997, 23, 603-616. [CrossRef] [PubMed]

21. Schnabel, H. An immune strain of Halobacterium halobium carries the invertible L segment of phage $\varphi \mathrm{H}$ as a plasmid. Proc. Natl. Acad. Sci. USA 1984, 81, 1017-1020. [CrossRef] [PubMed]

22. Schnabel, H.; Zillig, W.; Pfaffle, M.; Schnabel, R.; Michel, H.; Delius, H. Halobacterium halobium phage $\varphi \mathrm{H}$. EMBO J. 1982, 1, 87-92. [PubMed]

23. Pietilä, M.K.; Atanasova, N.S.; Manole, V.; Liljeroos, L.; Butcher, S.J.; Oksanen, H.M.; Bamford, D.H. Virion architecture unifies globally distributed pleolipoviruses infecting halophilic archaea. J. Virol. 2012, 86, 5067-5079. [CrossRef] [PubMed]

24. Pietilä, M.K.; Atanasova, N.S.; Oksanen, H.M.; Bamford, D.H. Modified coat protein forms the flexible spindle-shaped virion of haloarchaeal virus His1. Environ. Microbiol. 2013, 15, 1674-1686. [CrossRef] [PubMed]

25. Juez, G.; Rodriguez-Valera, F.; Ventosa, A.; Kushner, D.J. Haloarcula hispanica spec. nov. and Haloferax gibbonsii spec, nov., two new species of extremely halophilic archaebacteria. Syst. Appl. Microbiol. 1986, 8, 75-79. [CrossRef]

26. Bath, C.; Dyall-Smith, M.L. His1, an archaeal virus of the Fuselloviridae family that infects Haloarcula hispanica. J. Virol. 1998, 72, 9392-9395. [PubMed]

27. Bamford, D.H.; Ravantti, J.J.; Rönnholm, G.; Laurinavičius, S.; Kukkaro, P.; Dyall-Smith, M.; Somerharju, P.; Kalkkinen, N.; Bamford, J.K.H. Constituents of SH1, a novel lipid-containing virus infecting the halophilic euryarchaeon Haloarcula hispanica. J. Virol. 2005, 79, 9097-9107. [CrossRef] [PubMed]

28. Bath, C.; Cukalac, T.; Porter, K.; Dyall-Smith, M.L. His1 and His2 are distantly related, spindle-shaped haloviruses belonging to the novel virus group, Salterprovirus. Virology 2006, 350, 228-239. [CrossRef] [PubMed]

29. Kukkaro, P.; Bamford, D.H. Virus-host interactions in environments with a wide range of ionic strengths. Environ. Microbiol. Rep. 2009, 1, 71-77. [CrossRef] [PubMed]

30. Jaakkola, S.T.; Penttinen, R.K.; Vilen, S.T.; Jalasvuori, M.; Rönnholm, G.; Bamford, J.K.; Bamford, D.H.; Oksanen, H.M. Closely related archaeal Haloarcula hispanica icosahedral viruses HHIV-2 and SH1 have nonhomologous genes encoding host recognition functions. J. Virol. 2012, 86, 4734-4742. [CrossRef] [PubMed]

31. Porter, K.; Kukkaro, P.; Bamford, J.K.; Bath, C.; Kivelä, H.M.; Dyall-Smith, M.L.; Bamford, D.H. SH1: A novel, spherical halovirus isolated from an Australian hypersaline lake. Virology 2005, 335, 22-33. [CrossRef] [PubMed] 
32. Porter, K.; Tang, S.L.; Chen, C.P.; Chiang, P.W.; Hong, M.J.; Dyall-Smith, M. PH1: An archaeovirus of Haloarcula hispanica related to SH1 and HHIV-2. Archaea 2013. [CrossRef] [PubMed]

33. Atanasova, N.S.; Demina, T.A.; Buivydas, A.; Bamford, D.H.; Oksanen, H.M. Archaeal viruses multiply: Temporal screening in a solar saltern. Viruses 2015, 7, 1902-1926. [CrossRef] [PubMed]

34. Mei, Y.; He, C.; Huang, Y.; Liu, Y.; Zhang, Z.; Chen, X.; Shen, P. Salinity regulation of the interaction of halovirus SNJ1 with its host and alteration of the halovirus replication strategy to adapt to the variable ecosystem. PLoS ONE 2015, 10, e0123874. [CrossRef] [PubMed]

35. Jäälinoja, H.T.; Roine, E.; Laurinmäki, P.; Kivelä, H.M.; Bamford, D.H.; Butcher, S.J. Structure and host-cell interaction of SH1, a membrane-containing, halophilic euryarchaeal virus. Proc. Natl. Acad. Sci. USA 2008, 105, 8008-8013. [CrossRef] [PubMed]

36. Kivelä, H.M.; Roine, E.; Kukkaro, P.; Laurinavičius, S.; Somerharju, P.; Bamford, D.H. Quantitative dissociation of archaeal virus SH1 reveals distinct capsid proteins and a lipid core. Virology 2006, 356, 4-11. [CrossRef] [PubMed]

37. Gil-Carton, D.; Jaakkola, S.T.; Charro, D.; Peralta, B.; Castano-Diez, D.; Oksanen, H.M.; Bamford, D.H.; Abrescia, N.G. Insight into the assembly of viruses with vertical single beta-barrel major capsid proteins. Structure 2015, 23, 1866-1877. [CrossRef] [PubMed]

38. Senčilo, A.; Jacobs-Sera, D.; Russell, D.A.; Ko, C.C.; Bowman, C.A.; Atanasova, N.S.; Österlund, E.; Oksanen, H.M.; Bamford, D.H.; Hatfull, G.F.; et al. Snapshot of haloarchaeal tailed virus genomes. RNA Biol. 2013, 10, 803-816. [CrossRef] [PubMed]

39. Krupovič, M.; Prangishvili, D.; Hendrix, R.W.; Bamford, D.H. Genomics of bacterial and archaeal viruses: Dynamics within the prokaryotic virosphere. Microbiol. Mol. Biol. Rev. 2011, 75, 610-635. [CrossRef] [PubMed]

40. Hendrix, R.W. Bacteriophage genomics. Curr. Opin. Microbiol. 2003, 6, 506-511. [CrossRef] [PubMed]

41. Atanasova, N.S.; Roine, E.; Oren, A.; Bamford, D.H.; Oksanen, H.M. Global network of specific virus-host interactions in hypersaline environments. Environ. Microbiol. 2012, 14, 426-440. [CrossRef] [PubMed]

42. Krupovič, M.; Quemin, E.R.; Bamford, D.H.; Forterre, P.; Prangishvili, D. Unification of the globally distributed spindle-shaped viruses of the Archaea. J. Virol. 2014, 88, 2354-2358. [CrossRef] [PubMed]

43. Hong, C.; Pietilä, M.K.; Fu, C.J.; Schmid, M.F.; Bamford, D.H.; Chiu, W. Lemon-shaped halo archaeal virus His1 with uniform tail but variable capsid structure. Proc. Natl. Acad. Sci. USA 2015, 112, 2449-2454. [CrossRef] [PubMed]

44. Hanhijärvi, K.J.; Ziedaite, G.; Pietilä, M.K.; Haeggstrom, E.; Bamford, D.H. DNA ejection from an archaeal virus-A single-molecule approach. Biophys. J. 2013, 104, 2264-2272. [CrossRef] [PubMed]

45. Pietilä, M.K.; Roine, E.; Sencilo, A.; Bamford, D.H.; Oksanen, H.M. Pleolipoviridae, a newly proposed family comprising archaeal pleomorphic viruses with single-stranded or double-stranded DNA genomes. Arch. Virol. 2015. [CrossRef] [PubMed]

46. Porter, K.; Russ, B.E.; Dyall-Smith, M.L. Virus-host interactions in salt lakes. Curr. Opin. Microbiol. 2007, 10, 418-424. [CrossRef] [PubMed]

47. Roine, E.; Oksanen, H.M. Viruses from the hypersaline environment. In Halophiles and Hypersaline Environments: Current Research and Future Trends; Ventosa, A., Oren, A., Ma, Y., Eds.; Springer-Verlag: Berlin, Germany, 2011; pp. 153-172.

48. Daugelavičius, R.; Gaidelytè, A.; Cvirkaite-Krupovič, V.; Bamford, D.H. On-line monitoring of changes in host cell physiology during the one-step growth cycle of Bacillus phage Bam35. J. Microbiol. Methods. 2007, 69, 174-179. [CrossRef] [PubMed]

49. Daugelavičius, R.; Bamford, J.K.H.; Bamford, D.H. Changes in host cell energetics in response to bacteriophage PRD1 DNA entry. J. Bacteriol. 1997, 179, 5203-5210. [PubMed]

50. Kivelä, H.M.; Daugelavičius, R.; Hankkio, R.H.; Bamford, J.K.H.; Bamford, D.H. Penetration of membrane-containing double-stranded-DNA bacteriophage PM2 into Pseudoalteromonas hosts. J. Bacteriol. 2004, 186, 5342-5354. [CrossRef] [PubMed]

51. Krupovič, M.; Daugelavičius, R.; Bamford, D.H. A novel lysis system in PM2, a lipid-containing marine double-stranded DNA bacteriophage. Mol. Microbiol. 2007, 64, 1635-1648. [CrossRef] [PubMed]

52. Poranen, M.M.; Daugelavičius, R.; Ojala, P.M.; Hess, M.W.; Bamford, D.H. A novel virus-host cell membrane interaction: Membrane voltage-dependent endocytic-like entry of bacteriophage $\varphi 6$ nucleocapsid. J. Cell Biol. 1999, 147, 671-681. [CrossRef] [PubMed] 
53. Jakutytė, L.; Baptista, C.; Sao-Jose, C.; Daugelavičius, R.; Carballido-Lopez, R.; Tavares, P. Bacteriophage SPP1 infection of Bacillus subtilis: Evidence for a preferential polar route for entry in a Gram-positive bacterium. FEBS J. 2011, 278, 461. [CrossRef] [PubMed]

54. Nuttall, S.D.; Dyall-Smith, M.L. HF1 and HF2: Novel bacteriophages of halophilic archaea. Virology 1993, 197, 678-684. [CrossRef] [PubMed]

55. Dyall-Smith, M. Halohandbook: Protocols for Halobacterial Genetics. Available online: http:/ / www.microbiol.unimelb.edu.au/micro/staff/mds/ (accessed on 12 May 2009).

56. Adams, M.H. Bacteriophages; Interscience Publishers: New York, NY, USA, 1959.

57. Daugelavičius, R.; Bakienė, E.; Beržinskienè, J.; Bamford, D.H. Binding of lipophilic anions to microbial cells. Bioelectrochem. Bioenerg. 1997, 42, 263-274. [CrossRef]

58. Daugelavičius, R.; Bakienè, E.; Beržinskienè, J.; Bamford, D.H. Use of lipophilic anions for estimation of biomass and cell viability. Biotechnol. Bioeng. 2001, 71, 208-216. [CrossRef]

59. Mihali, C.; Vaum, N. Use of plasticizers for electrochemical sensors. In Recent Advances in Plasticizers; Luqman, M., Ed.; InTech: Baia Mare, Romania, 2012; pp. 125-140. Available online: http://www.intech open.com/books/recent-advances-in-plasticizers/use-of-plasticizers-for-electrochemicalsensors (accessed on 24 August 2015).

60. Woese, C.R.; Fox, G.E. Phylogenetic structure of prokaryotic domain: The primary kingdoms. Proc. Natl. Acad. Sci. USA 1977, 74, 5088-5090. [CrossRef] [PubMed]

61. Bhattacharya, A.; Kohrer, C.; Mandal, D.; RajBhandary, U.L. Nonsense suppression in archaea. Proc. Natl. Acad. Sci. USA 2015, 112, 6015-6020. [CrossRef] [PubMed]

62. Wirth, J.F.; Snyder, J.C.; Hochstein, R.A.; Ortmann, A.C.; Willits, D.A.; Douglas, T.; Young, M.J. Development of a genetic system for the archaeal virus Sulfolobus turreted icosahedral virus (STIV). Virology 2011, 415, 6-11. [CrossRef] [PubMed]

63. Porter, K.; Dyall-Smith, M.L. Transfection of haloarchaea by the DNAs of spindle and round haloviruses and the use of transposon mutagenesis to identify non-essential regions. Mol. Microbiol. 2008, 70, 1236-1245. [CrossRef] [PubMed]

64. Shao, Y.P.; Wang, I.N. Bacteriophage adsorption rate and optimal lysis time. Genetics 2008, 180, 471-482. [CrossRef] [PubMed]

65. Aalto, A.P.; Bitto, D.; Ravantti, J.J.; Bamford, D.H.; Huiskonen, J.T.; Oksanen, H.M. Snapshot of virus evolution in hypersaline environments from the characterization of a membrane-containing Salisaeta icosahedral phage 1. Proc. Natl. Acad. Sci. USA 2012, 109, 7079-7084. [CrossRef] [PubMed]

66. Pietilä, M.K.; Laurinmäki, P.; Russell, D.A.; Ko, C.C.; Jacobs-Sera, D.; Butcher, S.J.; Bamford, D.H.; Hendrix, R.W. Insights into head-tailed viruses infecting extremely halophilic archaea. J. Virol. 2013, 87, 3248-3260. [CrossRef] [PubMed]

67. Rajaure, M.; Berry, J.; Kongari, R.; Cahill, J.; Young, R. Membrane fusion during phage lysis. Proc. Natl. Acad. Sci. USA 2015, 112, 5497-5502. [CrossRef] [PubMed]

68. Young, R. Phage lysis: Three steps, three choices, one outcome. J. Microbiol. 2014, 52, 243-258. [CrossRef] [PubMed]

69. Casjens, S.R. The DNA-packaging nanomotor of tailed bacteriophages. Nat. Rev. Microbiol. 2011, 9, 647-657. [CrossRef] [PubMed]

(C) 2016 by the authors; licensee MDPI, Basel, Switzerland. This article is an open access article distributed under the terms and conditions of the Creative Commons by Attribution (CC-BY) license (http://creativecommons.org/licenses/by/4.0/). 